
osteoarthritis symptoms: a randomized, double-blind, placebocontrolled trial

\title{
Cheng Luo
}

Jiaxing Hengjie Biopharmaceutical Co. Ltd

Shalini Srivastava ( $\nabla$ shalini.s@vediclifesciences.com )

Vedic Lifesciences (India)

\section{Research Article}

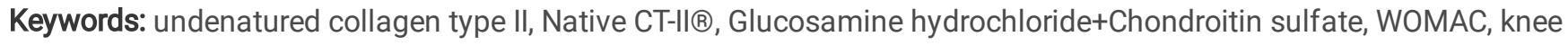
osteoarthritis

Posted Date: December 2nd, 2021

DOI: https://doi.org/10.21203/rs.3.rs-1080857/v1

License: () (i) This work is licensed under a Creative Commons Attribution 4.0 International License. Read Full License

Version of Record: A version of this preprint was published at Journal of Experimental Orthopaedics on December 23rd, 2022. See the published version at https://doi.org/10.1186/s40634-022-00559-8. 


\section{Abstract \\ Background}

Osteoarthritis (OA) of the knee is the most common type of arthritis, increasing with advancing age and external factors such as obesity. Joint health has historically relied on nutritional supplements derived from herbs and other natural products. Undenatured collagen type II demonstrated positive results with substantially lower therapeutic doses. Hence, the present study was designed to determine the efficacy and safety of Native CT-II ${ }^{\circledR}$, an undenatured type II collagen, on the symptomatic effects in individuals having joint pain due to $\mathrm{OA}$.

\section{Methods}

A randomized, double-blinded, placebo-controlled, parallel study was conducted on 101 slightly overweight volunteers, whose knee joint pain VAS score was $\geq 60$ had been included in the study for at least three months. The participants were divided into three groups, with similar demographic and baseline characteristics. The test product containing Native CT-II®, positive control containing $\mathrm{G}+\mathrm{C}$, and the placebo were taken six tablets per day for 84 consecutive days (Three capsules to be taken post-breakfast and three capsules post-dinner). Improvement in overall joint health in each participant from baseline to end of the study was measured by WOMAC, self-administered questionnaire in Native CT-IIß as compared to $\mathrm{G}+\mathrm{C}$ and placebo group.

\section{Results}

This study demonstrated that Native CT-IIß had an effective impact on the symptomatic effects of knee impairment associated with $\mathrm{OA}$ and in the quality of life of the participants. After 84 days, participants receiving Native $\mathrm{CT}-\| \circledast$ and $\mathrm{G}+\mathrm{C}$ had significant improvement in overall joint health as compared to participants receiving placebo.

\section{Conclusion}

Native CT-II@ was shown to be effective in relieving symptoms and improving quality of life for patients with knee joint pain associated with $O A$.

\section{Trial registration:}

The trial was registered with the clinical trial registry of the U.S. National Library of Medicine under National Institutes of Health (NIH) (https://clinicaltrials.gov/) with the National Clinical Trial (NCT) No: NCT04470336, Date of first registration: 14/07/2020.

\section{Introduction}

Knee osteoarthritis $(\mathrm{OA})$ is the most diagnosed form of arthritis, with its prevalence increasing with age, as well as external factors such as obesity [1]. The current global prevalence of knee OA has been estimated to be $16 \%$ in individuals who are 15 years and older, while the prevalence in individuals who are 40 years and older is stated to be $22.9 \%$ [2]. The global therapeutic market for OA is projected to reach USD 11.0 billion by 2021 due to the large geriatric and target patient population [3].

Non-steroidal anti-inflammatory drugs (NSAIDs) and physical exercise have been widely used as the first line of defense against symptomatic $\mathrm{OA}$, along with intra-articular corticosteroid and hyaluronic acid injections. Most of these treatment options do not alter the disease progression, but only aid in the alleviation of pain and disability. However, it has been reported that usage of these can lead to comorbidities and increased mortality $[1,4]$.

Nutritional supplements derived from herbs and other nature-based products have been historically used as an aid to improve joint health [5]. Glycosaminoglycan-based nutraceuticals such as Chondroitin Sulfate, Glucosamine Sulfate, etc., have been specially studied for their efficacy against OA; especially as they are vital components of the extracellular matrix and synovial fluid $[6,7]$. 
Evidence suggests that supplementation with these protects the joints against "wear and tear" while stimulating cartilage regeneration $[8,9]$. These have been proven to significantly reduce pain during $O A$ in numerous clinical trials, and are more tolerable than NSAIDs [10-13]. But the therapeutic dosage for these products is stated to be at least $1200 \mathrm{mg}$, which could pose significant compliance challenges [13].

Consumption of various forms of collagen, such as undenatured type II collagen, has also been studied for their potential benefits during OA management in pre-clinical and clinical studies, both demonstrating positive results with substantially lower therapeutic doses [14-16]. Based on the available literature, this study was designed to determine the efficacy and safety of Native CT-IIß, an undenatured type II collagen derived from the chicken sternum, on the symptomatic effects in individuals having joint pain due to OA.

\section{Methods}

\section{Participants}

Adults of either sex, complaining of knee pain having radiographical evidence of osteoarthritis were recruited for the study. Individuals with other joint-based conditions such as rheumatoid arthritis, osteoporosis, osteomyelitis, bone metastasis, and gout were excluded from the trial. Additional inclusion and exclusion criteria for the study have been stated in Table 1.

Table 1

Main Inclusion and Exclusion Criteria

\begin{tabular}{|ll|}
\hline Inclusion Criteria & Exclusion criteria \\
\hline 1. Age $\geq 40$ to $\leq 65$ years. & 1. Fasting Blood glucose $>125 \mathrm{mg} / \mathrm{dL}$. \\
\hline 2. Body Mass Index (BMI) $\geq 18.5$ and $\leq 29.9 \mathrm{~kg} / \mathrm{m}^{2}$ & $\begin{array}{l}\text { 2. Systolic blood pressure } \geq 140 \mathrm{mmHg} \text { and/or diastolic blood } \\
\text { pressure } \geq 90 \mathrm{mmHg} .\end{array}$ \\
\hline $\begin{array}{l}\text { 3. Non-vegetarians (Regardless of whether they eat } \\
\text { chicken, fish, goat mutton, pork, beef, or eggs). }\end{array}$ & $\begin{array}{l}\text { 3. Radiographic evidence of Grade I or Grade IV OA based on the } \\
\text { Kellgren and Lawrence (KL) radiographic criteria for osteoarthritis. }\end{array}$ \\
\hline $\begin{array}{l}\text { 4. Visual Analogue Scale (VAS) scores for knee joint } \\
\text { pain } \geq 60 .\end{array}$ & $\begin{array}{l}\text { 4. Any history of trauma, fractures, or surgery to the index joint or } \\
\text { used corticosteroids and hyaluronic acid. }\end{array}$ \\
\hline $\begin{array}{l}\text { 5. Willing to abstain from food containing type II } \\
\text { collagen from cartilage, e.g., chicken, fish, beef, etc. 48 } \\
\text { hours prior to all assessment visits. }\end{array}$ & $\begin{array}{l}\text { 5. Usage of local and/or nutraceutical analgesics along with NSAIDs } \\
\text { (including low dose aspirin } 50 \mathrm{mg} / \text { day for cardiovascular health) } \\
\text { associated with joint health and pain. }\end{array}$ \\
\hline
\end{tabular}

\section{Interventions}

The investigational product, Native CT-II®, contains undenatured type-II collagen derived from chicken sternum as described in Table 2. Previous studies have demonstrated that consumption of undenatured type-ll collagen in small doses is effective in improving joint health [17]. All the capsules manufactured for the study were matched for size, shape, color, and texture to preserve the blinding, with the plastic bottles being used for storage also being matched for size, color, and labelling. Acetaminophen was the only product allowed as a form of rescue medication at a dose of $1000 \mathrm{mg} /$ day, although participants had to abstain from rescue medication consumption for 48 hours prior to each study visit. 
Table 2

Investigational Product details

\begin{tabular}{|llll|}
\hline & Native CT-II & G+C & Placebo \\
\hline Composition & $\begin{array}{l}\text { Undenatured type-II collagen }(6.7 \mathrm{mg})+\text { D-glucose } \\
(443.3 \mathrm{mg})\end{array}$ & $\begin{array}{l}\text { Glucosamine Hydrochloride }(250 \\
\text { mg) }+ \\
\text { Chondroitin Sulfate }(200 \mathrm{mg})\end{array}$ & $\begin{array}{l}\text { D-glucose: } 450 \\
\text { mg }\end{array}$ \\
\hline $\begin{array}{l}\text { Total weight } \\
\begin{array}{l}\text { Dosage } \\
\text { form }\end{array}\end{array}$ & White opaque capsule & \\
\hline Regimen & Three capsules to be taken post-breakfast and three capsules post-dinner daily \\
\hline
\end{tabular}

\section{Study design and conduct}

A 12 week, randomized, double-blinded, placebo-controlled, parallel-group study was conceptualized to evaluate the efficacy and tolerability of Native CT-II® in participants having joint pain. Five hospitals were selected for conducting the clinical study, four in Mumbai and one in Varanasi, India. This study complies with the Declaration of Helsinki, ICH-GCP, and Ethical guidelines for biomedical research on human participants 2006, issued by the Indian Council of Medical Research (ICMR), India. The investigators explained all the participants about the objectives, procedures, risks and benefits involved in the study in understandable language. Only those participants who were willing to give written consent voluntarily were recruited in the study. The study results have been reported as per the Consolidated Standards of Reporting Trials (CONSORT) statement.

The first participant had their first screening visit on 10th July 2020, while the last participant's last visit was conducted on 12th April 2021. Before randomization, each participant had to comply with a seven-day placebo run-in period to identify placebo responders. Only participants with a mWOMAC score $\geq 75$ and no decrease in Pain VAS score when compared to screening, were randomized for further study. Stratified block randomization was performed using the Stats Direct Software version 3.1.17 using a block of 6 in the ratio 1:1:1 to receive the study product, comparator or the placebo. The group allocation was performed using the Interactive Web Response System (IWRS) on Clindox EDC by the research staff not directly involved in the study. The participant and the investigator were blinded to the treatment allocation. The participants were asked to report for the following visits after 28, 56 , and 84 days from randomization. Treatment compliance was ascertained for each participant through an IP diary that was to be filled by each participant, along with a record of rescue medication usage throughout the study. A record of the dispensed and returned medication was also maintained to confirm treatment compliance. Any adverse events that were experienced by the participants were to be recorded and reported to the investigator immediately, the information for the same being recorded in the source document and the e-CRF adverse event module. The blinding for the products was done using the blinding codes secured in tamper-evident sealed envelopes.

\section{Outcome measures}

\section{Primary outcome}

The WOMAC questionnaire [18], a self-administered questionnaire, has been modified and validated by the Center For Rheumatic Diseases (CRD) Pune in the Indian population [19]. The primary objective of the study was to see the effect of the 84 days of administration of the IP on the change in WOMAC total score.

\section{Secondary outcomes}

The secondary outcome for the study consisted of a change in WOMAC subscales of pain (scale of 0-4; averaged response of 5 questions), stiffness (scale of 0-4; averaged response for 2 questions), and physical function (scale of 0-4; averaged response for 17 questions) [20]. Other measures performed included health-related quality of life as evaluated by a validated EQ-5D-5L questionnaire consisting of 5 domains - mobility, self-care, usual activities, pain/discomfort, and anxiety/depression using 5 levels - no problems, slight problems, moderate problems, severe problems and extreme problems [21].

\section{Safety outcomes}

Page $4 / 17$ 
The pulse rate and blood pressure were both measured during the baseline and end of the study visits. Also, blood samples were collected during these visits to monitor the serum biochemical markers for liver and kidney function i.e., AST, ALT, ALP, and Serum creatinine. Furthermore, any adverse events and serious adverse events were to be monitored and reported to the investigator. The adverse events were to be recorded in the source document and the appropriate adverse event module in the eCRF.

\section{Statistical analysis}

Based on the data available for undenatured collagen clinical trials, a sample size of 30 evaluable participants per arm was deemed appropriate. With the assumption of approximately $20 \%$ of drop out and withdrawals during the study, 117 participants were recruited for the study. The primary and secondary efficacy variables are summarized descriptively using mean, standard deviation, median, confidence interval, and minimum and maximum values. The type I error probability associated with the null hypothesis test was set to 0.05 . The data was analyzed for the modified intention-to-treat (mITT) population i.e., participants who were randomized in the study and had at least completed the study designated visit on Day 28 . The baseline parameters were analyzed using the Chi-square and Mixed model Analysis of Variance (ANOVA) tests whereas the efficacy and safety parameters were also analyzed through the ANOVA test followed by a paired t-test to calculate the statistical significance between the study groups.

\section{Quality assurance}

The study was planned based on the ICH-GCP guidelines, with a pre-approved monitoring and audit plan to ensure the quality of data.

\section{Results}

A total of 101 participants were randomized into three study groups, with 34 participants in the Native CT-II® group, 33 in the G+C group, and 34 participants in the placebo group. One hundred and sixty-nine participants were screened for the study, with 39 participants being screening failures, 28 participants withdrawing or dropping out of the study before randomization and one participant being a randomization failure. Figure 1 below depicts the participant disposition for the study.

\section{Participant demographics and baseline characteristics}

The mean age for the randomized study population was stated to be $50.37(40.00,64.00)$ years, with no statistically significant difference between the groups; $p=0.2272$. Furthermore, most of the participants fell in the BMI overweight class between 25.00 to $29.9 \mathrm{~kg} / \mathrm{m}^{2}$, the BMI between each treatment group being statistically insignificant.; $p=0.6857$. As per the eligibility criteria, all the participants had a knee joint pain VAS score $\geq 60$ and the scores for each group were comparable during the baseline visit. The other demographic and baseline characteristics for the randomized study population are given in Table 3 
Table 3

Participant demographic and baseline characteristics

\begin{tabular}{|c|c|c|c|c|c|c|}
\hline Parameter & Categories & $\begin{array}{l}\text { Native CT-I® } \\
(\mathrm{N}=34)\end{array}$ & $\begin{array}{l}G+C \\
(N=33)\end{array}$ & $\begin{array}{l}\text { Placebo } \\
(\mathrm{N}=34)\end{array}$ & $\begin{array}{l}\text { Total } \\
(\mathrm{N}=101)\end{array}$ & $\begin{array}{l}\text { p- } \\
\text { value* }\end{array}$ \\
\hline \multirow[t]{3}{*}{ Age (Years) } & Mean & 50.94 & 51.48 & 48.71 & 50.37 & 0.2272 \\
\hline & SD & 7.13 & 6.44 & 7.31 & 7.01 & \\
\hline & $\begin{array}{l}\text { Range (Min., } \\
\text { Max.) }\end{array}$ & $(41.00,64.00)$ & $\begin{array}{l}(41.00 \\
64.00)\end{array}$ & $\begin{array}{l}(40.00 \\
64.00)\end{array}$ & $(40.00,64.00)$ & \\
\hline \multirow[t]{2}{*}{ Gender } & Female & $24(70.59 \%)$ & $19(57.58 \%)$ & $18(52.94 \%)$ & $61(60.40 \%)$ & 0.3048 \\
\hline & Male & $10(29.41 \%)$ & $14(42.42 \%)$ & $16(47.06 \%)$ & $40(39.60 \%)$ & \\
\hline \multirow[t]{3}{*}{ BMI $\left(\mathrm{kg} / \mathrm{m}^{2}\right)$} & Mean & 24.79 & 25.30 & 25.24 & 25.11 & 0.6857 \\
\hline & SD & 2.62 & 3.03 & 2.34 & 2.66 & \\
\hline & $\begin{array}{l}\text { Range (Min., } \\
\text { Max.) }\end{array}$ & $(19.19,29.59)$ & $\begin{array}{l}(18.63 \\
29.52)\end{array}$ & $\begin{array}{l}(21.19 \\
29.23)\end{array}$ & $(18.63,29.59)$ & \\
\hline \multirow[t]{2}{*}{ X-ray Grade } & Grade-II & $20(58.82 \%)$ & $20(60.61 \%)$ & $20(58.82 \%)$ & $60(59.41 \%)$ & 0.9855 \\
\hline & Grade-III & $14(41.18 \%)$ & $13(39.39 \%)$ & $14(41.18 \%)$ & $41(40.59 \%)$ & \\
\hline \multirow[t]{3}{*}{ Index Knee VAS Score } & Mean & 72.65 & 70.30 & 71.18 & 71.39 & 0.5338 \\
\hline & SD & 9.63 & 7.28 & 8.80 & 8.61 & \\
\hline & $\begin{array}{l}\text { Range (Min., } \\
\text { Max.) }\end{array}$ & $(60.00,90.00)$ & $\begin{array}{l}(60.00 \\
90.00)\end{array}$ & $\begin{array}{l}(60.00 \\
90.00)\end{array}$ & $(60.00,90.00)$ & \\
\hline \multirow[t]{3}{*}{ mWOMAC total score } & Mean & 86.06 & 86.67 & 86.45 & 86.39 & 0.9386 \\
\hline & SD & 7.57 & 7.21 & 6.46 & 7.03 & \\
\hline & $\begin{array}{l}\text { Range (Min., } \\
\text { Max.) }\end{array}$ & $\begin{array}{l}(75.00 \\
100.00)\end{array}$ & $\begin{array}{l}(75.00 \\
99.00)\end{array}$ & $\begin{array}{l}(75.00 \\
98.00)\end{array}$ & $\begin{array}{l}(75.00 \\
100.00)\end{array}$ & \\
\hline
\end{tabular}

\section{Effect of Native-CT $\|^{\circledR}$ on joint health}

The overall joint health as assessed by WOMAC total scores was comparable between all the study groups $(p=0.9386)$, at baseline. A significant reduction of the total scores from baseline was seen in all the treatment groups $(p<0.05)$ on Days 28,56 , and 84 . The change in the score for groups, when compared with the placebo, revealed that the Native CT-II® group had significantly after 28 days, and a similar change was observed in the $\mathrm{G}+\mathrm{C}$ group when compared to the placebo. Subsequently, at 84 days, both the Native $C T-I \circledast$ and $G+C$ groups showed a gradually greater reduction in the total score. Furthermore, despite the substantially lower dose, the reduction in the score for the Native $\mathrm{CT}-\mathrm{II}^{\circledR}$ group remained statistically and clinically comparable to $\mathrm{G}+\mathrm{C}$ as shown in Table 4 and 5. 
Table 4

Summary for WOMAC index total scores - mITT Population

\begin{tabular}{|lllll|}
\hline Visit (Day) & Categories & $\begin{array}{l}\text { Native CT-I® } \\
(\mathbf{N}=32)\end{array}$ & $\begin{array}{l}\text { G+C } \\
(\mathbf{N}=31)\end{array}$ & $\begin{array}{l}\text { Placebo } \\
\mathbf{( N = 3 1 )}\end{array}$ \\
\hline Baseline (Day 0) & $\mathbf{N}$ & 32 & 31 & 31 \\
& Mean & 85.91 & 87.03 & 86.45 \\
\cline { 2 - 5 } & SD & 7.21 & 7.17 & 6.67 \\
\cline { 2 - 5 } & Range (Min, Max) & $(75.00,99.00)$ & $(75.00,99.00)$ & $(75.00,98.00)$ \\
\hline Week 12 (Day 84) & $\mathbf{N}$ & 32 & 31 & 31 \\
\cline { 2 - 5 } & Mean & 53.44 & 53.29 & 72.61 \\
\cline { 2 - 5 } & SD & 18.40 & 22.27 & 19.11 \\
\cline { 2 - 5 } & Range (Min, Max) & $(27.00,97.00)$ & $(0.00,95.00)$ & $(22.00,103.00)$ \\
\hline Abbreviation: SD $=$ & Standard deviation, $n=$ Number of participants \\
\hline
\end{tabular}

Table 5: Absolute change in mWOMAC total scores (mITT population)

\begin{tabular}{|c|c|c|c|c|c|c|c|c|c|c|c|c|}
\hline \multirow{3}{*}{$\begin{array}{l}\text { Change } \\
\text { on Day } 84\end{array}$} & \multicolumn{4}{|c|}{ Native CT-II ${ }^{\circledR}(n=32)$} & \multicolumn{4}{|c|}{$G+C(n=31)$} & \multicolumn{4}{|c|}{ Placebo $(n=31)$} \\
\hline & \multirow{2}{*}{$\begin{array}{l}\text { Mean } \\
\text { (SD) }\end{array}$} & \multicolumn{2}{|l|}{$95 \% \mathrm{Cl}$} & \multirow{2}{*}{$\begin{array}{l}\text { p- } \\
\text { value* }\end{array}$} & \multirow{2}{*}{$\begin{array}{l}\text { Mean } \\
\text { (SD) }\end{array}$} & \multicolumn{2}{|l|}{$95 \% \mathrm{Cl}$} & \multirow{2}{*}{$\begin{array}{l}\text { p- } \\
\text { value* }\end{array}$} & \multirow{2}{*}{$\begin{array}{l}\text { Mean } \\
\text { (SD) }\end{array}$} & \multicolumn{2}{|l|}{$95 \% \mathrm{Cl}$} & \multirow{2}{*}{$\begin{array}{l}\mathrm{p}- \\
\text { value* }\end{array}$} \\
\hline & & Min & Max & & & Min & Max & & & Min & Max & \\
\hline $\begin{array}{l}\text { Total } \\
\text { mWOMAC } \\
\text { Score }\end{array}$ & -32.47 & -39.50 & -25.44 & $<.0001$ & -33.74 & -42.78 & -24.70 & $<.0001$ & -13.84 & -20.30 & -7.38 & $<.0001$ \\
\hline p-value ${ }^{\star \star}$ & 0.0003 & & & & 0.0003 & & & & & & & \\
\hline \multicolumn{13}{|c|}{ * $\mathrm{p}$ value calculated using paired t-test as compared to baseline. } \\
\hline \multicolumn{13}{|c|}{$\star \star p$ value calculated using ANCOVA as compared to placebo } \\
\hline \multicolumn{13}{|c|}{ Abbreviation: SD - Standard deviation, $\mathrm{n}$ - Number of participants, $\mathrm{Cl}$ - Confidence Interval } \\
\hline
\end{tabular}

\section{Effect of Native-CT II ${ }^{\circledR}$ on pain}

The baseline mWOMAC-P subscale scores for all the treatment groups were comparable $(p>0.05)$ as presented in Table 6 . Withingroup analysis for all the treatment groups demonstrated a statistically significant difference being observed in each group for all the study visits when compared to the baseline, with the extent of reduction increasing with the longer treatment duration. However, through intergroup analysis, it was observed that while the absolute change in the mWOMAC-P scores for the $\mathrm{G}+\mathrm{C}$ group were statistically significant when compared to the placebo $(p<0.05)$ for all the study visits, the statistical difference when comparing the Native CT-II ${ }^{\circledR}$ and placebo group absolute changes in mWOMAC-P scores was only significant for the Day 56 and 84 visits. There was no statistically significant difference observed between the changes in the scores of the Native CT-II ${ }^{\circledR}$ and $\mathrm{G}+\mathrm{C}$ groups (Day 84: $\mathrm{p}=0.9777$ ) (Table 7).

\section{Effect of Native-CT II ${ }^{\circledR}$ on stiffness}

The baseline mWOMAC-S subscale scores for all the treatment groups were comparable $(p>0.05)$. For this subscale, the withingroup analysis for all the treatment groups demonstrated a statistically significant difference being observed in the Native CT-II ${ }^{\circledR}$ 
and the $\mathrm{G}+\mathrm{C}$ group for all the study visits when compared to the baseline, with the extent of reduction increasing with the longer treatment duration. Within the placebo group, the significant difference was only observed during the Day 56 and 84 visits. When both the Native CT-II ${ }^{\circledR}$ and $\mathrm{G}+\mathrm{C}$ group change in scores was compared with that of the placebo, each of the groups showed a statistically significant difference during all the treatment visits. Furthermore, no statistically significant difference was observed between the changes in the scores of the Native $C T-I^{\circledR}$ and the $G+C$ groups (Day 84: $p=0.7035$ ) (Table 6 and 7).

\section{Effect of Native-CT I® ${ }^{\circledR}$ on physical function}

The baseline mWOMAC-PF subscale scores for all the treatment groups were comparable $(p>0.05)$. Within-group analysis for all the treatment groups demonstrated a statistically significant difference being observed in each group for all the study visits when compared to the baseline, with the extent of reduction increasing with longer treatment duration. Again, when both the Native CT$\| \circledast$ and $\mathrm{G}+\mathrm{C}$ group change in scores was compared with that of the placebo, each of the groups showed a statistically significant difference during all the treatment visits. Furthermore, no statistically significant difference was observed between the changes in the scores of the Native CT-II and the G+C groups (Day 84: $p=0.9445$ ) (Table 6 and 7).

Table 6

Summary- mWOMAC subscale scores (mITT population)

\begin{tabular}{|c|c|c|c|c|}
\hline Visit (Day) & Categories & $\begin{array}{l}\text { Native CT-I® } \\
(\mathrm{N}=32)\end{array}$ & $\begin{array}{l}G+C \\
(N=31)\end{array}$ & $\begin{array}{l}\text { Placebo } \\
(\mathrm{N}=31)\end{array}$ \\
\hline \multicolumn{5}{|c|}{ WOMAC Pain Scores } \\
\hline \multirow[t]{3}{*}{ Baseline (Day 0) } & $\mathbf{N}$ & 32 & 31 & 31 \\
\hline & Mean (SD) & $14.41( \pm 2.08)$ & $14.90( \pm 1.92)$ & $14.61( \pm 1,93)$ \\
\hline & Range (Min., Max.) & $(11.00,19.00)$ & $(11.00,19.00)$ & $(11.00,19.00)$ \\
\hline \multirow[t]{3}{*}{ Week 12 (Day 84) } & $\mathbf{N}$ & 32 & 31 & 31 \\
\hline & Mean (SD) & 8.72 & 8.87 & 11.90 \\
\hline & Range (Min., Max.) & $(4.00,17.00)$ & $(0.00,20.00)$ & $(3.00,19.00)$ \\
\hline \multicolumn{5}{|c|}{ WOMAC Stiffness Scores } \\
\hline \multirow[t]{3}{*}{ Baseline (Day 0) } & $\mathbf{N}$ & 32 & 31 & 31 \\
\hline & Mean (SD) & $5.94( \pm 1.01)$ & $6.42( \pm 0.92)$ & $6.23( \pm 0.92)$ \\
\hline & Range (Min., Max.) & $(3.00,8.00)$ & $(5.00,8.00)$ & $(5.00,8.00)$ \\
\hline \multirow[t]{3}{*}{ Week 12 (Day 84) } & $\mathbf{n}$ & 32 & 31 & 31 \\
\hline & Mean (SD) & $3.75( \pm 1.32)$ & $3.71( \pm 1.79)$ & $5.39( \pm 1.58)$ \\
\hline & Range (Min., Max.) & $(2.00,7.00)$ & $(0.00,8.00)$ & $(2.00,7.00)$ \\
\hline \multicolumn{5}{|c|}{ WOMAC Physical Function Scores } \\
\hline \multirow[t]{3}{*}{ Baseline (Day 0) } & $\mathbf{n}$ & 32 & 31 & 31 \\
\hline & Mean & $65.56( \pm 5.45)$ & $65.71( \pm 5.88)$ & $65.61( \pm 4.89)$ \\
\hline & Range (Min., Max.) & $(55.00,75.00)$ & $(55.00,75.00)$ & $(55.00,73.00)$ \\
\hline \multirow[t]{3}{*}{ Week 12 (Day 84) } & $\mathrm{n}$ & 32 & 31 & 31 \\
\hline & Mean & $40.97( \pm 14.01)$ & 40.71( \pm 16.69$)$ & $55.32( \pm 14.02)$ \\
\hline & Range (Min., Max.) & $(20.00,74.00)$ & $(0.00,72.00)$ & $(16.00,77.00)$ \\
\hline
\end{tabular}


Table 7

Change-mWOMAC subscale scores (mITT population)

\begin{tabular}{|c|c|c|c|c|c|c|c|c|c|c|c|c|}
\hline \multicolumn{13}{|c|}{ mWOMAC-Pain } \\
\hline \multirow{4}{*}{$\begin{array}{l}\text { Change } \\
\text { on Day } \\
84\end{array}$} & \multicolumn{4}{|c|}{ Native CT- I® $(n=32)$} & \multicolumn{4}{|c|}{$G+C(n=31)$} & \multicolumn{4}{|c|}{ Placebo $(n=31)$} \\
\hline & \multirow{2}{*}{$\begin{array}{l}\text { Mean } \\
\text { (SD) }\end{array}$} & \multicolumn{2}{|l|}{$95 \% \mathrm{Cl}$} & \multirow{2}{*}{$\begin{array}{l}\text { p- } \\
\text { value* }\end{array}$} & \multirow{2}{*}{$\begin{array}{l}\text { Mean } \\
\text { (SD) }\end{array}$} & \multicolumn{2}{|l|}{$95 \% \mathrm{Cl}$} & \multirow{2}{*}{$\begin{array}{l}\text { p- } \\
\text { value* }\end{array}$} & \multirow{2}{*}{$\begin{array}{l}\text { Mean } \\
\text { (SD) }\end{array}$} & \multicolumn{2}{|l|}{$95 \% \mathrm{Cl}$} & \multirow{2}{*}{$\begin{array}{l}\text { p- } \\
\text { value* }\end{array}$} \\
\hline & & Min & Max & & & Min & Max & & & Min & Max & \\
\hline & $\begin{array}{l}-5.69 \\
(3.66)\end{array}$ & -7.01 & -4.37 & $<.0001$ & $\begin{array}{l}-6.03 \\
(4.72)\end{array}$ & -7.76 & -4.30 & $<.0001$ & $\begin{array}{l}-2.71 \\
(3.95)\end{array}$ & -4.16 & -1.26 & 0.0006 \\
\hline $\begin{array}{l}\text { p- } \\
\text { value** }\end{array}$ & 0.0024 & & & & 0.0024 & & & & & & & \\
\hline \multicolumn{13}{|c|}{ mWOMAC-Stiffness } \\
\hline \multirow{4}{*}{$\begin{array}{l}\text { Change } \\
\text { on Day } \\
84\end{array}$} & \multicolumn{4}{|c|}{ Native CT-I@ $(n=32)$} & \multicolumn{4}{|c|}{$G+C(n=31)$} & \multicolumn{4}{|c|}{ Placebo $(n=31)$} \\
\hline & \multirow{2}{*}{$\begin{array}{l}\text { Mean } \\
\text { (SD) }\end{array}$} & \multicolumn{2}{|l|}{$95 \% \mathrm{Cl}$} & \multirow{2}{*}{$\begin{array}{l}\text { p- } \\
\text { value* }\end{array}$} & \multirow{2}{*}{$\begin{array}{l}\text { Mean } \\
\text { (SD) }\end{array}$} & \multicolumn{2}{|l|}{$95 \% \mathrm{Cl}$} & \multirow{2}{*}{$\begin{array}{l}\text { p- } \\
\text { value* }\end{array}$} & \multirow{2}{*}{$\begin{array}{l}\text { Mean } \\
\text { (SD) }\end{array}$} & \multicolumn{2}{|l|}{$95 \% \mathrm{Cl}$} & \multirow{2}{*}{$\begin{array}{l}\text { p- } \\
\text { value* }\end{array}$} \\
\hline & & Min & Max & & & Min & Max & & & Min & Max & \\
\hline & $\begin{array}{l}-2.19 \\
(1.75)\end{array}$ & -2.82 & -1.56 & $<.0001$ & $\begin{array}{l}-2.71 \\
(2.05)\end{array}$ & -3.46 & -1.96 & $<.0001$ & $\begin{array}{l}-0.84 \\
(1.27)\end{array}$ & -1.30 & -0.37 & 0.0009 \\
\hline $\begin{array}{l}\text { p- } \\
\text { value** }\end{array}$ & 0.0002 & & & & $<.0001$ & & & & & & & \\
\hline \multicolumn{13}{|c|}{ mWOMAC- Physical Function } \\
\hline \multirow{4}{*}{$\begin{array}{l}\text { Change } \\
\text { on Day } \\
84\end{array}$} & \multicolumn{4}{|c|}{ Native CT-I@ (n= 32) } & \multicolumn{3}{|c|}{$G+C(n=31)$} & & Placebo & $n=31)$ & & \\
\hline & Mean & $95 \% \mathrm{Cl}$ & & p- & Mean & $95 \% \mathrm{Cl}$ & & p- & Mean & $95 \% \mathrm{Cl}$ & & p- \\
\hline & & Min & Max & & & Min & Max & & & Min & Max & \\
\hline & $\begin{array}{l}-24.59 \\
(15.00)\end{array}$ & -30.00 & -19.19 & $<.0001$ & $\begin{array}{l}-25.00 \\
(18.90)\end{array}$ & -31.93 & -18.07 & $<.0001$ & $\begin{array}{l}-10.29 \\
(13.07)\end{array}$ & -15.08 & -5.50 & 0.0001 \\
\hline $\begin{array}{l}\text { p- } \\
\text { value** }\end{array}$ & 0.0003 & & & & 0.0002 & & & & & & & \\
\hline${ }^{*} p$ value & culated & ing pai & t-test & compar & to base & & & & & & & \\
\hline${ }^{\star *} p$ value & calculatec & using Al & COVA as & mpared & to placebc & & & & & & & \\
\hline Abbrevia & n: SD - S & ndard c & eviation, I & Numbe & f partici & nts, Cl - & onfider & Interva & & & & \\
\hline
\end{tabular}

\section{Effect of Native-CT I ${ }^{\circledR}$ on quality of life (EQ-5D-5L)}

During the baseline visit, the scores for each of the 5 domains and the VAS assessment were comparable between all the study groups ( $p>0.05$ ). After the treatment period of 84 days, a significant difference was seen within all the study domains and the VAS scale when compared to the baseline. Furthermore, the absolute change within the Native CT-II® was statistically significant when compared to the placebo for four of the 5 domains, except for the "anxiety or depression" domain, as well as the VAS score. The same trend was seen within the G+C group scores, however, Native CT-II® saw a more significant change in the "Usual activities" than in the $\mathrm{G}+\mathrm{C}$ group when compared to placebo ( $p=0.0156 \& p=0.1997$ respectively) (Table 8). 
Change in EQ-5D-5L scores (mITT population)

\begin{tabular}{|c|c|c|c|c|c|c|c|c|c|c|c|c|}
\hline \multicolumn{13}{|c|}{ EQ-5D Mobility } \\
\hline \multirow{4}{*}{$\begin{array}{l}\text { Change } \\
\text { on Day } \\
84\end{array}$} & \multicolumn{4}{|c|}{ Native CT-II $(n=30)$} & \multicolumn{4}{|c|}{$G+C(n=29)$} & \multicolumn{4}{|c|}{ Placebo $(n=30)$} \\
\hline & \multirow{2}{*}{$\begin{array}{l}\text { Mean } \\
\text { (SD) }\end{array}$} & \multicolumn{2}{|c|}{ 95\% C.I. } & \multirow{2}{*}{$\begin{array}{l}\text { p- } \\
\text { value* }\end{array}$} & \multirow{2}{*}{$\begin{array}{l}\text { Mean } \\
\text { (SD) }\end{array}$} & \multicolumn{2}{|c|}{ 95\% C.I. } & \multirow{2}{*}{$\begin{array}{l}\text { p- } \\
\text { value* }\end{array}$} & \multirow{2}{*}{$\begin{array}{l}\text { Mean } \\
\text { (SD) }\end{array}$} & \multicolumn{2}{|c|}{ 95\% C.I. } & \multirow{2}{*}{$\begin{array}{l}\text { p- } \\
\text { value* }\end{array}$} \\
\hline & & Min & Max & & & Min & Max & & & Min & Max & \\
\hline & $\begin{array}{l}-1.00 \\
(0.74)\end{array}$ & -1.28 & -0.72 & $<.0001$ & $\begin{array}{l}-1.21 \\
(0.73)\end{array}$ & -1.48 & -0.93 & $<.0001$ & $\begin{array}{l}-0.73 \\
(0.98)\end{array}$ & -1.10 & -0.37 & 0.0003 \\
\hline p-value** & 0.0255 & & & & 0.0179 & & & & & & & \\
\hline \multicolumn{13}{|c|}{ EQ-5D Self Care } \\
\hline \multirow{4}{*}{$\begin{array}{l}\text { Change } \\
\text { on Day } \\
84\end{array}$} & \multicolumn{4}{|c|}{ Native CT- I® $(n=30)$} & \multicolumn{4}{|c|}{$G+C(n=29)$} & \multicolumn{4}{|c|}{ Placebo $(n=30)$} \\
\hline & \multirow{2}{*}{$\begin{array}{l}\text { Mean } \\
\text { (SD) }\end{array}$} & \multicolumn{2}{|c|}{ 95\% C.I. } & \multirow{2}{*}{$\begin{array}{l}\text { p- } \\
\text { value* }\end{array}$} & \multirow{2}{*}{$\begin{array}{l}\text { Mean } \\
\text { (SD) }\end{array}$} & \multicolumn{2}{|c|}{ 95\% C.I. } & \multirow{2}{*}{$\begin{array}{l}\text { p- } \\
\text { value* }\end{array}$} & \multirow{2}{*}{$\begin{array}{l}\text { Mean } \\
\text { (SD) }\end{array}$} & \multicolumn{2}{|c|}{ 95\% C.I. } & p- \\
\hline & & Min & Max & & & Min & Max & & & Min & Max & \\
\hline & $\begin{array}{l}-0.90 \\
(0.84)\end{array}$ & -1.22 & -0.58 & $<.0001$ & $\begin{array}{l}-1.00 \\
(0.89)\end{array}$ & -1.34 & -0.66 & $<.0001$ & $\begin{array}{l}-0.47 \\
(0.97)\end{array}$ & -0.83 & -0.10 & 0.0136 \\
\hline p-value ${ }^{\star \star}$ & 0.0112 & & & & 0.0340 & & & & & & & \\
\hline EQ-5D Usu & Activitie & & & & & & & & & & & \\
\hline Change & Native & $\| \circledast(n=$ & & & $G+C(n$ & & & & Placeb & $n=30)$ & & \\
\hline 84 & Mean & $95 \%$ & & & Mean & $95 \% \mathrm{C}$ & & p- & Mean & $95 \% \mathrm{C}$ & & p- \\
\hline & & Min & Max & & & Min & Max & & & Min & Max & \\
\hline & $\begin{array}{l}-1.17 \\
(0.87)\end{array}$ & -1.49 & 0.84 & $<.0001$ & $\begin{array}{l}-0.93 \\
(0.92)\end{array}$ & -1.28 & -0.58 & $<.0001$ & $\begin{array}{l}-0.83 \\
(1.02)\end{array}$ & -1.21 & -0.45 & 0.0001 \\
\hline p-value** & 0.0156 & & & & 0.1997 & & & & & & & \\
\hline EQ-5D Pair & or Discor & & & & & & & & & & & \\
\hline Change & Native & $\| \circledast(n=$ & & & $G+C(n$ & & & & Placeb & $n=30)$ & & \\
\hline 84 & Mean & $95 \%$ & & & Mean & $95 \% \mathrm{C}$ & & p- & Mean & $95 \% \mathrm{C}$ & & p- \\
\hline & & Min & Max & $\begin{array}{l}\text { p- } \\
\text { value* }\end{array}$ & & Min & Max & & & Min & Max & \\
\hline & $\begin{array}{l}-1.13 \\
(0.68)\end{array}$ & -1.39 & -0.88 & $<.0001$ & $\begin{array}{l}-0.97 \\
(1.02)\end{array}$ & -1.35 & -0.58 & $<.0001$ & $\begin{array}{l}-0.60 \\
(0.72)\end{array}$ & -0.87 & -0.33 & $<.0001$ \\
\hline p-value** & 0.0020 & & & & 0.0117 & & & & & & & \\
\hline EQ-5D Anx & ty or Dep & ssion & & & & & & & & & & \\
\hline Change & Native & $\| \circledast(n=$ & & & $G+C(n$ & & & & Placeb & $n=30)$ & & \\
\hline 84 & Mean & $95 \%$ & & p- & Mean & $95 \% \mathrm{C}$ & & p- & Mean & $95 \%$ C & & p- \\
\hline & & Min & Max & & & Min & Max & & & Min & Max & \\
\hline & $\begin{array}{l}-0.90 \\
(0.76)\end{array}$ & -1.18 & -0.62 & $<.0001$ & $\begin{array}{l}-1.00 \\
(1.07)\end{array}$ & -1.41 & -0.59 & $<.0001$ & $\begin{array}{l}-0.93 \\
(1.17)\end{array}$ & -1.37 & -0.50 & 0.0001 \\
\hline p-value ${ }^{\star \star}$ & 0.3435 & & & & 0.2770 & & & & & & & \\
\hline EQ-5D VAS & Score & & & & & & & & & & & \\
\hline $\begin{array}{l}\text { Change } \\
\text { on Day }\end{array}$ & Native & $\| \circledast(n=$ & & & $G+C(n$ & & & & Placeb & $n=30)$ & & \\
\hline
\end{tabular}




\begin{tabular}{|c|c|c|c|c|c|c|c|c|c|c|c|c|}
\hline \multicolumn{13}{|c|}{ EQ-5D Mobility } \\
\hline \multirow[t]{3}{*}{84} & \multirow{2}{*}{$\begin{array}{l}\text { Mean } \\
\text { (SD) }\end{array}$} & \multicolumn{2}{|c|}{ 95\% C.I. } & \multirow{2}{*}{$\begin{array}{l}\text { p- } \\
\text { value* }\end{array}$} & \multirow{2}{*}{$\begin{array}{l}\text { Mean } \\
\text { (SD) }\end{array}$} & \multicolumn{2}{|c|}{ 95\% C.I. } & \multirow{2}{*}{$\begin{array}{l}\text { p- } \\
\text { value* }\end{array}$} & \multirow{2}{*}{$\begin{array}{l}\text { Mean } \\
\text { (SD) }\end{array}$} & \multicolumn{2}{|c|}{ 95\% C.I. } & \multirow{2}{*}{$\begin{array}{l}\text { p- } \\
\text { value* }\end{array}$} \\
\hline & & Min & Max & & & Min & Max & & & Min & Max & \\
\hline & $\begin{array}{l}17.73 \\
(13.78)\end{array}$ & 12.59 & 22.88 & $<.0001$ & $\begin{array}{l}18.97 \\
(15.55)\end{array}$ & 13.05 & 24.88 & $<.0001$ & $\begin{array}{l}4.50 \\
(13.73)\end{array}$ & -0.63 & 9.63 & 0.0831 \\
\hline $\begin{array}{l}\text { p-value** } \\
\text { vs. } \\
\text { placebo }\end{array}$ & 0.0003 & & & & 0.0009 & & & & & & & \\
\hline
\end{tabular}

\section{Safety evaluations}

No statistically significant difference was found in the Pulse rate and blood pressure values during baseline ( $p>0.05)$. Random changes were found in mean blood pressure and pulse rate at the end of the treatment period; however, they did not have any pattern and were deemed to be random type 1 errors. Furthermore, none of the changes in any of the values were beyond the normal range.

An insignificant decrease in the AST levels was observed in the $\mathrm{G}+\mathrm{C}$ and the placebo groups when compared to their baseline values. Similar decreases were observed in all the study groups for the other biomarkers, however, none of the changes were statistically significant when compared to baseline, or the other study groups. Furthermore, the levels for each of the biomarkers did not change beyond the normal range.

All but one, the adverse events (AEs) reported in the study were mild and resolved completely. None of the AEs observed in any of the groups were related to the study products. The serious adverse event observed in the study was reported for the participant diagnosed with COVID-19 and was definitely not related to the study product.

\section{Discussion}

Joint wear and tear have been acknowledged to be a cause of great disability and isolation in the older population [22].

Numerous nutraceuticals have been developed over the past couple of decades to combat joint impairment, especially due to osteoarthritis. This was mainly done to avoid the use of invasive techniques and therapies such as NSAIDs that would lead to extreme discomfort side-effects. Some of the compounds being used in India for this purpose include Collagen peptide, Chondroitin sulfate, Glucosamine sulfate, Fish oil, Boswellia, Green tea, Ginger, and Rosehip extracts [23].

Even as these products are used in the nutraceutical market, the clinical evidence available does not conclusively support the utilization of some of the specified products [24], with inconclusive results or limited effects being observed in clinical trials conducted for fish oil [25], collagen hydrolysate [26], chondroitin sulfate [27], glucosamine [28], rose hip [29], etc. [28]. The only products that have been clinically proven to be effective in OA management include Boswellia, curcumin, pycnogenol, methylsulfonylmethane, and undenatured type II collagen [28]. Out of these products, undenatured type II collagen is one of the few products that provides a significant effect at a relatively low dose $[16,30]$. The treatment duration for the trials vary between 4 weeks to 3 years, and the dosage is low only in undenatured type Il collagen (40 mg/day) and pycnogenol (50 mg/day), while it was as high as $100 \mathrm{mg} /$ day for Boswellia serrate, $800 \mathrm{mg}$ to $1200 \mathrm{mg} /$ day for Chondroitin sulphate, $1500 \mathrm{mg} /$ day for Glucosamine hydrochloride or glucosamine sulfate and $10 \mathrm{~g} /$ day for Collagen hydrolysate [24].

One of the studies with the Boswellia serrata extract showed a significant improvement in physical function, pain, and stiffness after consumption of $174.6 \mathrm{mg}$ active ingredient per day for a treatment duration of 120 days. Even radiographical improvements were observed in the study through an improved knee joint gap and reduced osteophytes [31]. Numerous other studies observed 
that, even as the onset of improvement through the consumption of these extracts was slow, their long terms effects and persistence after treatment were comparable or even better than known NSAIDs such as valdecoxib and ibuprofen. The dosage of Boswellia serrata extract in the studies was $999 \mathrm{mg} /$ day and $100 \mathrm{mg} /$ day respectively [32, 33].

In addition to this, the combination of Glucosamine Hydrochloride \& Chondroitin Sulfate has been utilized worldwide to treat OA, with studies still being underway to evaluate its further efficacy, with mixed results. Many of the studies proved the efficacy of the products in reducing the symptoms of OA after a treatment duration of 12 weeks [34, 35], even comparing the effects to known NSAIDs such as celecoxib [36]. The use of these in combination with other products such as quercetin and manganese ascorbate have also shown statistical improvements in the management and treatment of OA when compared to placebo [37]. Risk assessment for Glucosamine and Chondroitin Sulfate demonstrated a dose of $2000 \mathrm{mg} /$ day for glucosamine and $1200 \mathrm{mg} / \mathrm{day}$ for chondroitin sulfate to be the observed safe level for consumption, the aforementioned concentrations being the highest doses consumed in human clinical trials showing an efficacy without notable adverse events [38]. However, some clinical trials did not demonstrate the same efficacy towards OA management as stated above [39, 40].

A study conducted to evaluate the efficacy of undenatured type II collagen observed that the WOMAC score for the undenatured type II collagen reduced by $33 \%$ from baseline while it reduced by only $14 \%$ in participants in the G+C group after a treatment period of 90 days, the reduction between both the groups being statistically significant [16]. Through these studies, it can be concluded that undenatured type-II collagen has a proven efficacy towards OA symptomatic relief, even proving to be equal or better than $\mathrm{G}+\mathrm{C}$ in some cases, as was seen due to the statistically comparable reduction in scores. Longer treatment duration for the current study may have reflected similar results as observed in the two aforementioned studies.

In addition to the symptomatic presentation of $\mathrm{OA}$, the joint impairment associated with knee pain in $\mathrm{OA}$ also has a negative impact on a person's quality of life (QoL) [41]. It has been observed that the onset of OA has an impact on multiple facets of a person's life, including physical and mental aspects [42]. The limitations in the activity that arise due to OA progressions impact the psychological well-being and social life of individuals, thus reducing their quality of life. This is why assessing the quality of life in patients with $\mathrm{OA}$ is stated to be crucial to comprehend the full impact of the disease and assess any improvements achieved through various treatments [43].

To evaluate the impact of the product on the participants' quality of life, the EQ-5D-5L questionnaire was utilized in this study. At the end of the 84-day treatment period, each domain in the EQ-5D-5L showed a statistically significant improvement in QoL for participants of the Native CT-IIß group when compared to the placebo, except for the "anxiety or depression" domain. Again, the scores of Native CT-IIB and $\mathrm{G}+\mathrm{C}$ were comparable for all the domains at the end of the treatment period, even as the reduction in mean "usual activities" and "pain or discomfort" scores in the Native CT-IIß group was numerically greater than the G+C group.

Furthermore, safety assessments conducted on the tested dose did not reveal any safety or tolerability concerns throughout the treatment duration. Even the adverse events recorded during the study did not have any relation to the study products.

This study demonstrated that Native CT-IIß had an effective impact on the symptomatic effects of knee impairment associated with $\mathrm{OA}$ and in the quality of life of the participants. The most improvement in all the assessments was observed by the end of the study (day 84), thus it can be postulated that further symptomatic and QoL benefits would emanate with even longer chronic dosing periods.

\section{Conclusion}

This study demonstrated the efficacious effect of Native CT-IIß in symptomatic relief and quality life associated with knee joint pain in OA. Even at a dosage of $\sim 40 \mathrm{mg}$, the Native CT-II® showed comparable results when compared to the reference product combination of Glucosamine $\mathrm{HCl} \&$ chondroitin sulfate at a dose of $2700 \mathrm{mg}$. It can also be observed that the product would demonstrate better therapeutic efficacy at a higher dose. Future studies involving Native CT-II® need to be conducted to assess the wider efficacy profile of the product at higher doses in a larger population.

\section{Abbreviations}

Page $12 / 17$ 
AEs: Adverse events

ALP: Alkaline phosphatase

ALT: Alanine aminotransferase

AST: Aspartate aminotransferase

BMI: Body mass index

C.I.: Confidence interval

CRD: Center for Rheumatic Diseases

eCRF: electronic Case Report Form

G+C: Glucosamine Hydrochloride + Chondroitin Sulfate

ICF: Informed Consent Form

ICH-GCP: International Conference on Harmonization - Good Clinical Practice

IEC: Independent Ethics Committee

ITT: Intention to treat

K/L: Kellgren-Lawrence

mITT: modified Intention to treat

mWOMAC: modified Western Ontario and McMaster Universities

NCT: National Clinical Trial

$\mathrm{NIH}$ : National Institutes of Health

NSAIDs: Nonsteroidal anti-inflammatory drugs

OA: Osteoarthritis

PP: Per protocol

QoL: Quality of Life

SD: Standard deviation

TMF: Trial Master File

VAS: Visual Analogue Scale

\section{Declarations}

\section{Ethics committee approval and consent to participate}

The ACEAS-Independent Ethics Committee, Ahmedabad, India approved (letter No. and monitored the study (CDSCO Reg. No. ECR/281/Indt/GJ/2017 and OHRP \& DHHS Reg, No. IRB00011046) for Mumbai sites and Sadbhawana Hospital Ethics Committee, Varanasi (Reg. No.: ECR/667/Inst/UP/2017) approved and monitored the study at Varanasi site. All the participants voluntarily provided a signed and dated written informed consent form before enrolment into the study. 


\section{Consent for publication}

Not applicable

\section{Availability of data and materials}

The data used/analyzed in the study are not publicly available due to a confidentiality agreement with the sponsor. Data are however available from the authors upon reasonable request and with permission of Jiaxing Hengjie Biopharmaceutical Co. Ltd., Zhejiang, China.

\section{Competing Interests}

Cheng Lou is Director, Department of Research and Development, Jiaxing Hengjie Biopharmaceutical Co. Ltd., Zhejiang, China. The other author declared that no competing interest exists.

\section{Funding}

The study was funded by the Jiaxing Hengjie Biopharmaceutical Co. Ltd., Zhejiang, China.

\section{Authors' contributions}

CL approved the final manuscript. SS conceptualised the study, supervised the preparation of the manuscript, and reviewed the final manuscript.

\section{Acknowledgments}

The clinical trial was carried out by the clinical research organization Vedic Lifesciences Pvt. Ltd., Mumbai, India. The study products were provided by the Jiaxing Hengjie Biopharmaceutical Co. Ltd., Zhejiang, China

\section{References}

1. Hsu, H. \& Siwiec, R. M.. Knee Osteoarthritis. In: StatPearls. Treasure Island (FL):StatPearls Publishing; 2021

2. Cui, A. et al. Global, regional prevalence, incidence and risk factors of knee osteoarthritis in population-based studies.EClinicalMedicine [Internet]. 2020;29-30

3. Osteoarthritis Therapeutics Market - Global Forecast to 2025 | MarketsandMarkets [Internet]. 2020

4. Osama, A., Zakir, H., Abdel, S. \& Yegappan, K. Treatment modalities for hip and knee osteoarthritis: A systematic review of safety. J Orthop Surg (Hong Kong) [Internet]. 2018 Sep 1;26(3)

5. Kamble, S., Patil, A., Shinde, S. \& Ankush, H. A review on current nutraceuticals in the management of osteoarthritis. Int $J$ Hortic Food Sci [Internet], 3 (1), 22-8 (2021).

6. Desai, A., Shendge, N. P. \& Anand, S. S. Evidence-based nutraceuticals for osteoarthritis: A review. Int J Orthop Sci [Internet], 7 (2), 846-53 (2021).

7. Gupta, R. C., Lall, R. \& Srivastava, A. Nutraceuticals: efficacy, safety, and toxicity. 2021

8. Kirkham, S. \& Samarasinghe, R. Review article: Glucosamine. J Orthop Surg (Hong Kong) [Internet], 17 (1), $72-6$ (2009).

9. Henrotin, Y., Mobasheri, A. \& Marty, M. Is there any scientific evidence for the use of glucosamine in the management of human osteoarthritis? Arthritis Res Ther [Internet], 14 (1), 201 (2012).

10. Lomonte, A. B. V., Mendonça, J. A., Brandão, G. \& de Castro, C. Multicenter, randomized, double-blind clinical trial to evaluate efficacy and safety of combined glucosamine sulfate and chondroitin sulfate capsules for treating knee osteoarthritis. Adv 
Rheumatol (London, England) [Internet], 58 (1), 41 (2018).

11. Qiu, G. X., Gao, S. N., Giacovelli, G., Rovati, L. \& Setnikar, I. Efficacy and safety of glucosamine sulfate versus ibuprofen in patients with knee osteoarthritis. Arzneimittelforschung, 48 (5), 469-474 (1998).

12. Jackson, C. et al. The human pharmacokinetics of oral ingestion of glucosamine and chondroitin sulfate taken separately or in combination. Osteoarthr Cartil [Internet], 18 (3), 297-302 (2010).

13. Jerosch, J. Effects of Glucosamine and Chondroitin Sulfate on Cartilage Metabolism in OA: Outlook on Other Nutrient Partners Especially Omega-3 Fatty Acids.Int J Rheumatol [Internet]. 2011;2011.

14. Lugo, J. P., Saiyed, Z. M. \& Lane, N. E. Efficacy and tolerability of an undenatured type II collagen supplement in modulating knee osteoarthritis symptoms: a multicenter randomized, double-blind, placebo-controlled study. Nutr J [Internet], 15, 14 (2016).

15. Orhan, C. et al. Undenatured Type II Collagen Ameliorates Inflammatory Responses and Articular Cartilage Damage in the Rat Model of Osteoarthritis. Front Vet Sci, 8, 617789 (2021).

16. Crowley, D. et al. Safety and efficacy of undenatured type II collagen in the treatment of osteoarthritis of the knee: a clinical trial. Int J Med Sci [Internet], 6 (6), 312-21 (2009).

17. Lugo, J. et al. Undenatured type II collagen (UC-II $)$ for joint support: a randomized, double-blind, placebo-controlled study in healthy volunteers. J Int Soc Sports Nutr [Internet], 10, 48 (2013).

18. Roos, E., Klässbo, M. \& Lohmander, L. WOMAC osteoarthritis index. Reliability, validity, and responsiveness in patients with arthroscopically assessed osteoarthritis. Western Ontario and MacMaster Universities. Scand J Rheumatol [Internet], 28 (4), 210-5 (1999).

19. Chopra, A., Lavin, P., Patwardhan, B. \& Chitre, D. A 32-week randomized, placebo-controlled clinical evaluation of RA-11, an Ayurvedic drug, on osteoarthritis of the knees. J Clin Rheumatol [Internet], 10 (5), 236-45 (2004).

20. Chopra, A., Lavin, P., Patwardhan, B. \& Chitre, D. Randomized double blind trial of an ayurvedic plant derived formulation for treatment of rheumatoid arthritis. J Rheumatol, 27 (6), 1365-1372 (2000).

21. Bilbao, A. et al. Psychometric properties of the EQ-5D-5L in patients with hip or knee osteoarthritis: reliability, validity and responsiveness. Qual life Res [Internet]. 2018 Nov 1;27(11):2897-908

22. Hughes, S. L., Dunlop, D., Edelman, P., Chang, R. W. \& Singer, R. H. Impact of joint impairment on longitudinal disability in elderly persons.Journals Gerontol [Internet]. 1994;49(6)

23. Vaishya, R., Agarwal, A., Shah, A., Vijay, V. \& Vaish, A. Current status of top 10 nutraceuticals used for Knee Osteoarthritis in India. J Clin Orthop trauma [Internet], 9 (4), 338-48 (2018).

24. Liu, X., Eyles, J., McLachlan, A. \& Mobasheri, A. Which supplements can I recommend to my osteoarthritis patients? Rheumatology (Oxford) [Internet], 57 (suppl_4), iv75-87 (2018).

25. Stammers, T., Sibbald, B. \& Freeling, P. Efficacy of cod liver oil as an adjunct to non-steroidal anti-inflammatory drug treatment in the management of osteoarthritis in general practice. Ann Rheum Dis [Internet], 51, 128 (1992).

26. Vijven, J. et al. Symptomatic and chondroprotective treatment with collagen derivatives in osteoarthritis: a systematic review. Osteoarthr Cartil [Internet], 20 (8), 809-21 (2012).

27. Singh, J., Noorbaloochi, S., MacDonald, R. \& Maxwell, L. Chondroitin for osteoarthritis.Cochrane database Syst Rev [Internet]. $2015 ; 1(6)$

28. Liu, X., Machado, G., Eyles, J., Ravi, V. \& Hunter, D. Dietary supplements for treating osteoarthritis: a systematic review and meta-analysis. Br J Sports Med [Internet], 52 (3), 167-75 (2018).

29. Christensen, R., Bartels, E., Altman, R., Astrup, A. \& Bliddal, H. Does the hip powder of Rosa canina (rosehip) reduce pain in osteoarthritis patients?-a meta-analysis of randomized controlled trials. Osteoarthr Cartil [Internet], 16 (9), 965-72 (2008).

30. Lugo, J. P., Saiyed, Z. M. \& Lane, N. E. Efficacy and tolerability of an undenatured type II collagen supplement in modulating knee osteoarthritis symptoms: a multicenter randomized, double-blind, placebo-controlled study. Nutr J [Internet], 15, 14 (2016).

31. Majeed, M., Majeed, S., Narayanan, N. \& Nagabhushanam, K. A pilot, randomized, double-blind, placebo-controlled trial to assess the safety and efficacy of a novel Boswellia serrata extract in the management of osteoarthritis of the knee. Phytother 
Res [Internet], 33 (5), 1457-68 (2019).

32. Sontakke, S. et al. Open, randomized, controlled clinical trial of Boswellia serrata extract as compared to valdecoxib in osteoarthritis of knee. Indian J. Pharmacol, 39, 27 (2007).

33. Karimifar, M., Soltani, R., Hajhashemi, V. \& Sarrafchi, S. Evaluation of the effect of Elaeagnus angustifolia alone and combined with Boswellia thurifera compared with ibuprofen in patients with knee osteoarthritis: a randomized double-blind controlled clinical trial. Clin Rheumatol [Internet], 36 (8), 1849-53 (2017).

34. Nguyen, P., Mohamed, S., Gardiner, D. \& Salinas, T. A randomized double-blind clinical trial of the effect of chondroitin sulfate and glucosamine hydrochloride on temporomandibular joint disorders: a pilot study. Cranio [Internet], 19 (2), 130-9 (2001).

35. Sterzi, S. et al. The efficacy and safety of a combination of glucosamine hydrochloride, chondroitin sulfate and bio-curcumin with exercise in the treatment of knee osteoarthritis: a randomized, double-blind, placebo-controlled study. Eur J Phys Rehabil Med [Internet], 52 (3), 321-30 (2016).

36. Hochberg, M. C. et al. double-blind, multicenter, non inferiority clinical trial with combined glucosamine and chondroitin sulfate vs celecoxib for painful knee osteoarthritis. Osteoarthr Cartil [Internet], 22, S25 (2014).

37. Das, A. \& Hammad, T. Efficacy of a combination of FCHG49 glucosamine hydrochloride, TRH122 low molecular weight sodium chondroitin sulfate and manganese ascorbate in the management of knee osteoarthritis. Osteoarthr Cartil [Internet], 8 (5), 343-50 (2000).

38. Hathcock, J. \& Shao, A. Risk assessment for glucosamine and chondroitin sulfate. Regul Toxicol Pharmacol [Internet], 47 (1), 78-83 (2007).

39. Fransen, M. et al. Glucosamine and chondroitin for knee osteoarthritis: a double-blind randomised placebo-controlled clinical trial evaluating single and combination regimens. Ann Rheum Dis [Internet], 74 (5), 851-8 (2015).

40. Roman-Blas, J., Castañeda, S., Sánchez-Pernaute, O., Largo, R. \& Herrero-Beaumont, G. Combined Treatment With Chondroitin Sulfate and Glucosamine Sulfate Shows No Superiority Over Placebo for Reduction of Joint Pain and Functional Impairment in Patients With Knee Osteoarthritis: A Six-Month Multicenter, Randomized, Double-Blind, Placebo-Co. Arthritis Rheumatol (Hoboken, NJ) [Internet]. 2017;69(1):77-85

41. Lespasio, M. J. et al. Knee Osteoarthritis: A Primer. Perm J [Internet], 21, 16-183 (2017).

42. Salaffi, F., Carotti, M., Stancati, A. \& Grassi, W. Health-related quality of life in older adults with symptomatic hip and knee osteoarthritis: a comparison with matched healthy controls. Aging Clin Exp Res [Internet], 17 (4), 255-63 (2005).

43. Vitaloni, M. et al. Global management of patients with knee osteoarthritis begins with quality of life assessment: a systematic review. BMC Musculoskelet Disord [Internet], 20 (1), 493 (2019).

\section{Figures}




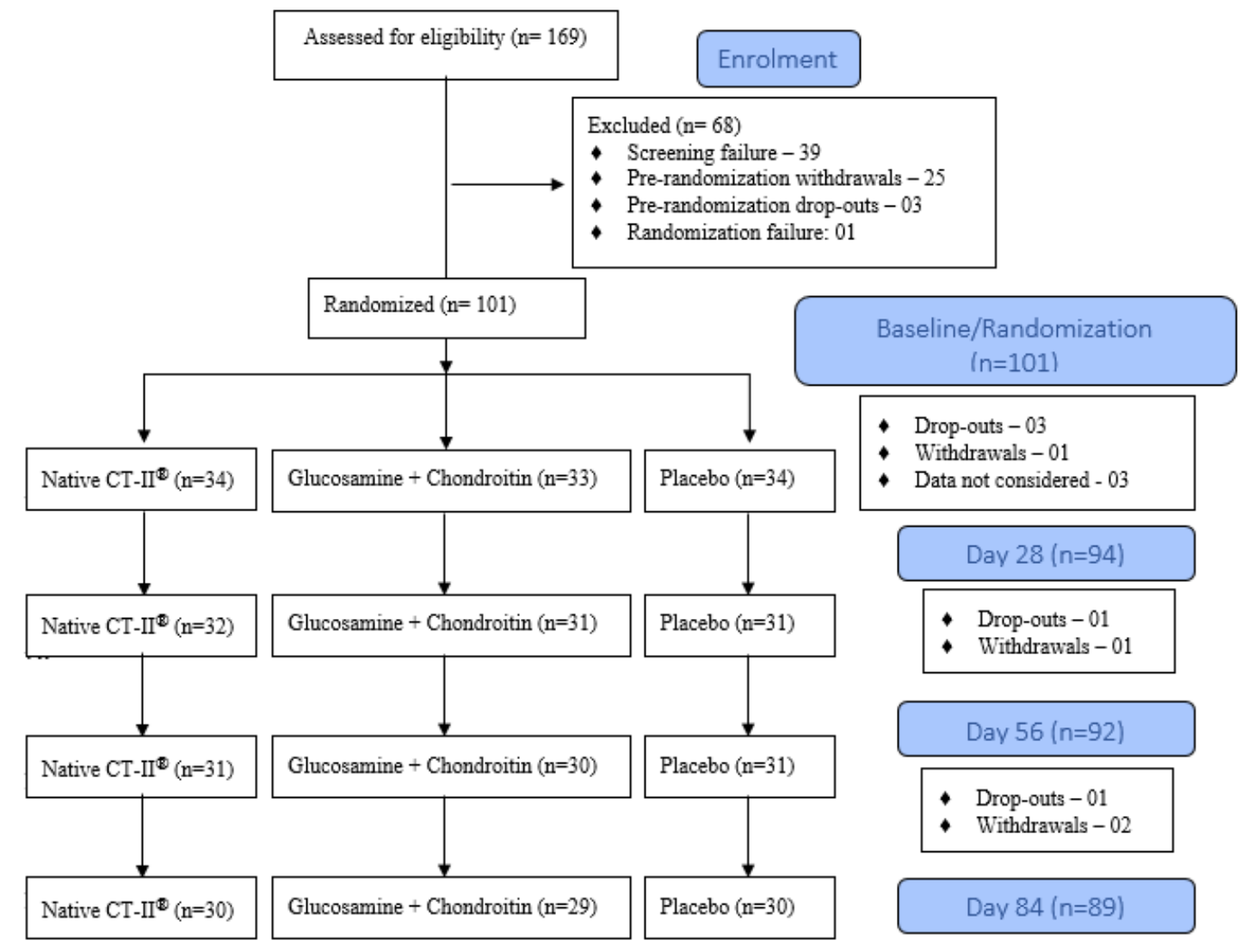

\section{Figure 1}

Participant Disposition

\section{Supplementary Files}

This is a list of supplementary files associated with this preprint. Click to download.

- Supplementaryfile.xlsx 